\title{
Selective Methylmagnesium Chloride Mediated Acetylations of Isosorbide: A Route to Powerful Nitric Oxide Donor Furoxans
}

\author{
Patrick Kielty, ${ }^{\dagger}$ Dennis A. Smith, ${ }^{\dagger}$ Peter Cannon, ${ }^{\ddagger}$ Michael P. Carty ${ }^{\S}$ Michael Kennedy, ${ }^{\dagger}$ Patrick \\ McArdle, ${ }^{\dagger}$ Richard J. Singer, ${ }^{\|}$and Fawaz Aldabbagh ${ }^{*},+$,
}

† School of Chemistry, National University of Ireland Galway, University Road, Galway, H91 TK33, Ireland

‡Avara Pharmaceutical Services, Shannon Industrial Estate, Shannon, Co. Clare, V14 FXog, Ireland

$\S$ Biochemistry, School of Natural Sciences, National University of Ireland Galway, University Road, Galway, H91

TK33, Ireland

I| Department of Chemical and Pharmaceutical Sciences, School of Life Sciences, Pharmacy \& Chemistry, Kingston University, Penrhyn Road, Kingston upon Thames, KT1 2EE, UK

$\perp$ Present address: Department of Pharmacy, School of Life Sciences, Pharmacy \& Chemistry, Kingston University, Penrhyn Road, Kingston upon Thames, KT1 2EE, UK

\begin{abstract}
Isosorbide was functionalized with furoxan for the first time to give adducts that release nitric oxide up to 7.5 times faster than the commercial vasodilator, isosorbide-5-mononitrate ( $\mathrm{Is}_{5} \mathrm{~N}$ ). The synthesis was facilitated by $\mathrm{MeMgCl}$-mediated selective acetylation of isosorbide or selective deacetylation of isosorbide-2,5diacetate, which was rationalised in terms of a more stable 5alkoxide magnesium salt using DFT. Isosorbide-furoxans are safer to handle than Is5 $\mathrm{N}$ due to greater thermal stability.
\end{abstract}

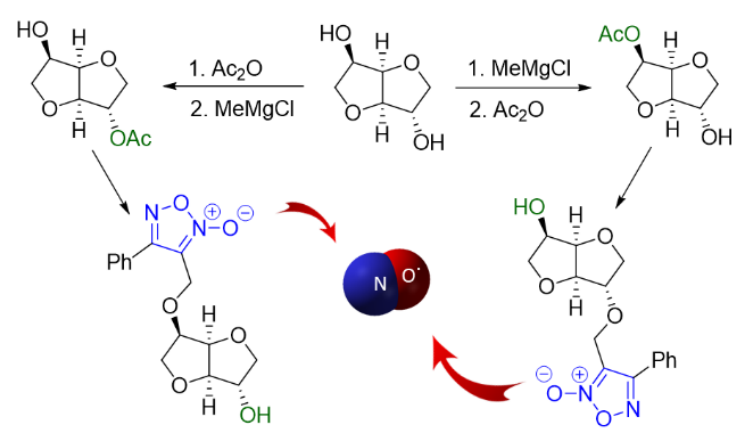

Nitric oxide (NO) is a reactive free radical with a vast array of physiological functions, ${ }^{1}$ in cancer, $^{2}$ anti-microbial processes, 3 wound healing,4 and most significantly, vasodilation. 5 Clinically, nitrate ester drugs are used to effect vasodilation. Nitroglycerin, pentaerythritol tetranitrate, isosorbide dinitrate (IsDiN), and isosorbide-5-mononitrate (Is5N $\mathbf{N}$, Scheme $1 \mathrm{~A}$ ) are prescribed to patients suffering from angina, where released NO induces relaxation of vascular smooth muscles (vasodilation) to reduce blood pressure. ${ }^{6}$ Nitrate esters however, are well-known explosives,7 including IsDiN, a particularly hazardous side-product in the manufacture of Is 5 N. ${ }^{8}$ Furoxans (1,2,5-oxadiazole 2-oxides) are highly energetic molecules, ${ }^{9}$ heralded as alternative NOdonors. ${ }^{10-15}$ The Cassella-Hoechst drug, CAS 1609, is a furoxan with potent and long-lasting vasodilation, ${ }^{10,11}$ and is devoid of the tolerance associated with nitrate ester drugs. ${ }^{16}$ Isosorbide (1) is a sustainable feed-stock industrially produced from the double dehydration of D-sorbitol. ${ }^{17}$ Apart from the nitrate esters, there are few valuable derivatives of $\mathbf{1}$ due to difficulties in selective functionalization and substitution at the 2- and 5-hydroxyl groups. ${ }^{18}$ Herein, for the first time, furoxan is combined with isosorbide (1), and in doing so, we have developed a simple and selective acetylation protectiondeprotection protocol for scaffold $\mathbf{1}$ (Scheme $1 \mathrm{~B}$ ).
Scheme 1. (A) Is5N and furoxan drugs (B) Protectiondeprotection of isosorbide 1 allowing selective functionalization with furoxan
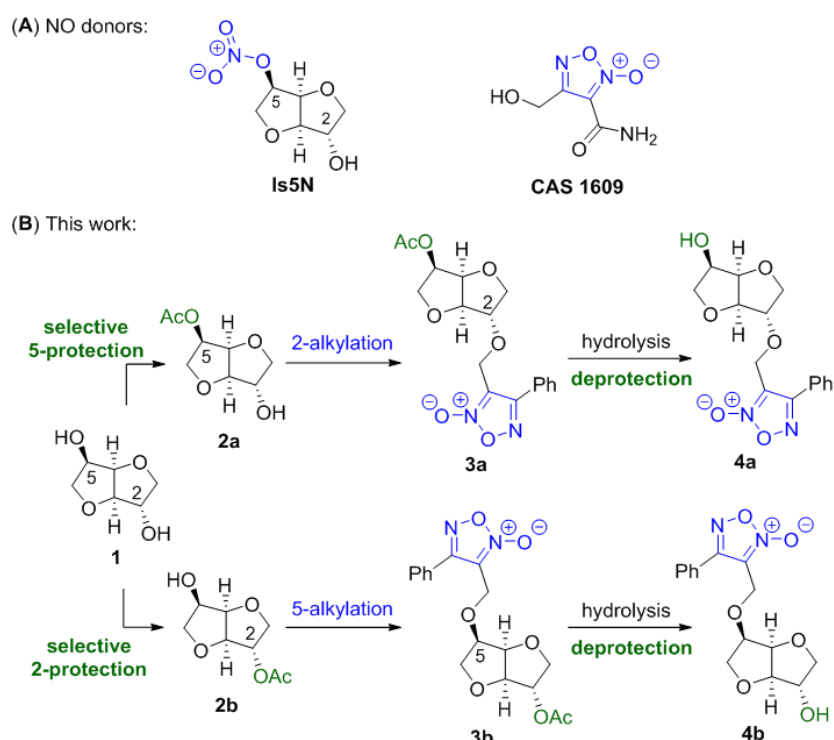
The two hydroxyls of 1 are non-equivalent with an exo 2$\mathrm{OH}$ and endo $5-\mathrm{OH}$ having different reactivities. The more nucleophilic nature of the $5-\mathrm{OH}$ is attributed to activation via $\mathrm{H}$-bonding with the oxygen of the adjacent cycle. ${ }^{19}$ Despite the difference in reactivity, base-mediated acetylations and alkylations are unreliable and low yielding, with the only reported selective acetylation of 1 using harmful $\mathrm{PbO}$ in $\mathrm{Ac}_{2} \mathrm{O}$ to give isosorbide-5-acetate (2a). ${ }^{20}$ Acetylation with $\mathrm{Ac}_{2} \mathrm{O}$ alone gives mixtures of isosorbide acetates with 5 -acetate 2 a the major product, but in low recovered yields. ${ }^{21}$ The literature reported syntheses of isosorbide-2-acetate (2b) are inadequately selective with significant draw-backs. Preparations of $\mathbf{2} \mathbf{b}$ have used DCCmediated coupling with poor atom-economy, ${ }^{22}$ and reducedpressure distillation from mixtures of isosorbide-acetates. ${ }^{20}$ More specialized enzyme-mediated acetylation of $\mathbf{1}$, and enzyme-mediated hydrolysis of isosorbide-2,5-diacetate 5 have been reported. ${ }^{23}$ Inexpensive $\mathrm{MeMgCl}$ has found application as a non-nucleophilic base, including in the Roche AG industrial deprotonation of secondary amines and $\alpha$-deprotonation of nitriles. ${ }^{24}$ Herein, the selective acetylation of the $2-\mathrm{OH}$ and $5-\mathrm{OH}$ of 1 was achieved by simply altering the number of equivalents of $\mathrm{MeMgCl}$, as part of a protection-deprotection strategy that allowed facile alkylation to give unique furoxan $\mathrm{NO}$-donors in high yields.

$\mathrm{NaH}$ and $\mathrm{BuLi}$ in combination with $\mathrm{Ac}_{2} \mathrm{O}$ gave low conversions with little selectivity toward the 2- or 5-positions of isosorbide 1 (Table 1 ). $\mathrm{MeMgCl}$ (1.1 equiv) and $\mathrm{Ac}_{2} \mathrm{O}$ provided high conversion and selectivity for acetylation at the 5 -position, with 5 -acetate $\mathbf{2 a}$ isolated in $73 \%$ yield. By simply increasing the amount of $\mathrm{MeMgCl}$ ( $>2$ equiv), a switch in selectivity of acetylation was achieved with the isomeric 2-acetate $\mathbf{2 b}$ as the major product, occurring in a ratio of $45: 1$ over 2a. Conversion was low, however, and replacing $\mathrm{Ac}_{2} \mathrm{O}$ with more reactive $\mathrm{AcCl}$ enabled near complete conversion of $\mathbf{1}$ to $\mathbf{2} \mathbf{b}$ in $78 \%$ isolated yield, with trace levels $(<0.5 \%)$ of isomer $\mathbf{2 a}$ detected by GC (Figure S2).

Table 1. Optimizing the formation of $2 a$ and $2 b$

\begin{tabular}{|c|c|c|c|c|}
\hline 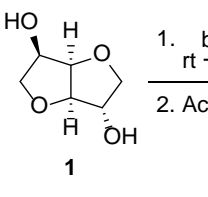 & $\begin{array}{l}\text { THF } \\
\mathrm{dx}, 0.5 \mathrm{~h} \\
1 \text { equiv) } \\
\mathrm{x}, 2 \mathrm{~h}\end{array}$ & $\left\langle\sum_{\substack{\overline{\mathrm{H}} \\
\mathbf{2 a}}}^{\mathrm{AcO}}\right.$ & ${ }^{\mathrm{HO}} \stackrel{\mathrm{H}}{=} \mathrm{O}$ & $\sum_{\bar{i}}^{\sum_{\bar{H}}^{O}}$ \\
\hline base (equiv) & $\mathbf{1}(\%)^{a}$ & $\mathbf{2 a}(\%)^{b}$ & $\mathbf{2 b}(\%)^{b}$ & $5(\%)^{b}$ \\
\hline $\mathrm{NaH}(1.1)$ & 47 & 30 & 8 & 15 \\
\hline BuLi (1.1) & 24 & 40 & 12 & 25 \\
\hline $\mathrm{MeMgCl}(1.1)$ & 10 & $76(73)^{c}$ & 2 & 13 \\
\hline $\operatorname{MeMgCl}(2.8)$ & 43 & 1 & 45 & 11 \\
\hline $\operatorname{MeMgCl}(2.8)^{d}$ & 6 & - & $82(78)^{c}$ & 12 \\
\hline $\operatorname{MeMgCl}(1.3)^{e}$ & 3 & - & $88(83)^{c}$ & 9 \\
\hline
\end{tabular}

See Table S1 for full list of optimization experiments. ${ }^{a}$ Conversion determined by gravimetry. ${ }^{b}$ Conversion determined by GC. ${ }^{c}$ Isolated yield. ${ }^{d} \mathrm{o}{ }^{\circ} \mathrm{C}, \mathrm{AcCl}$ (1 equiv) as acetylation agent. ${ }^{e} \mathrm{Ac}_{2} \mathrm{O}$ (2.5 equiv), Amberlite ${ }^{\circledR} \mathrm{IR}-12 \mathrm{O}, 2 \mathrm{~h}, 80{ }^{\circ} \mathrm{C}$, then filtration, evaporation and addition of $\mathrm{MeMgCl}$, THF, reflux, $8 \mathrm{~h}$.
DFT modelling was used to investigate this remarkable selectivity of deprotonation by assessing the stability of $+\mathrm{MgCl}$ complex $\mathbf{6 a}$ relative to $\mathbf{6 c}$ (Scheme 2 ) formed through ethereal (THF-like) ${ }^{25}$ chelation to the adjacent ring oxygen atom in the isosorbide substrate. DFT was carried out in the gas phase, since solvent effects (the role of THF) would not affect the relative energies of the observed isosorbide complexes. Two conformations of $\mathbf{1}$ were of interest; the minimum energy model and an alternative conformer $1.0 \mathrm{kcal} / \mathrm{mol}$ higher in energy. Starting from the minimum energy conformer $\mathbf{1}$, coordination of the $+\mathrm{MgCl}$ ion was preferred at the 5 -alkoxide $6 \mathbf{a}$ by $11.7 \mathrm{kcal} / \mathrm{mol}$ over the strained 2-alkoxide $\mathbf{6 c}$. The greater stability of $\mathbf{6 a}$ arises from more effective $+\mathrm{MgCl}$ coordination to the oxygen atom on the adjacent ring with steric hindrance from the isosorbide junction 3,4-hydrogens affecting coordination in complex $\mathbf{6 c}$. The energy minimum conformation of $\mathbf{1}$ preferentially gave 2-alkoxide complex $\mathbf{6 b}$, with ethereal $+\mathrm{MgCl}$ coordination within the same ring, over 2-alkoxide $6 \mathrm{c}$ by $2.7 \mathrm{kcal} / \mathrm{mol}$. Moreover, ${ }^{+} \mathrm{MgCl}$ coordination to 2 -alkoxide $\mathbf{6 c}$ was only possible using the higher energy alternative conformer of $\mathbf{1}$. The enhanced stability of 5-alkoxide 6a over 2-alkoxide complexes $\mathbf{6 b}$ and $\mathbf{6 c}$ was reflected in shorter $\mathrm{Mg}^{+} . . . \mathrm{OR}$ (alkoxide) and $\mathrm{Mg}^{+} \ldots \mathrm{OR}_{2}$ (ether) bond distances (Table $\mathrm{S}_{3}$ ).

Scheme 2. DFT of proposed alkoxide intermediates from the reaction of isosorbide 1 with $\mathrm{MeMgCl}^{a}$

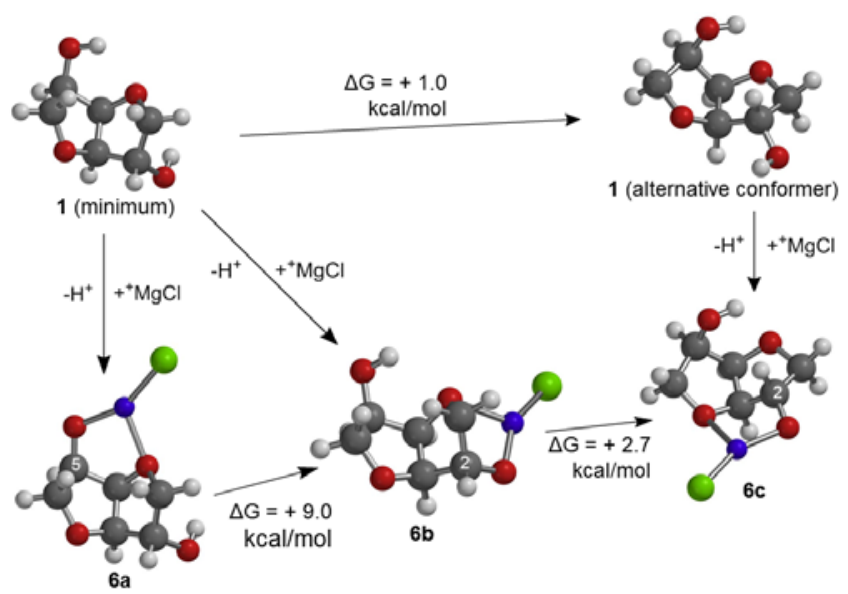

${ }^{a}$ All geometry optimizations were performed using Gaussian $16 \mathrm{~W} /$ GaussView 6 with DFT B 3 LYP functional in the gas phase and a $6311 \mathrm{G}(2 \mathrm{~d}, \mathrm{p})$ basis set. ${ }^{26} \mathrm{Mg}$ and $\mathrm{Cl}$ atoms depicted in blue and green, respectively. Table S2 contains model energies in Hartrees.

Upon addition of >2 equiv of $\mathrm{MeMgCl}$, both the 2- and 5OHs of 1 were deprotonated, and acetylation occurred at the less stable, more reactive 2-alkoxide, delivering a switch in selectivity to give $\mathbf{2 b}$. DFT modelling supported the greater stabilization of ${ }^{+} \mathrm{MgCl}$ at the 5 -alkoxide in the 2,5 dialkoxide complex with shorter bond lengths between $\mathrm{Mg}^{+} \ldots$-OR(alkoxide) and $\mathrm{Mg}^{+} \ldots \mathrm{OR}_{2}$ (ether) compared with ${ }^{+} \mathrm{MgCl}$ coordination at the 2-position (Figure $\mathrm{S}_{3}$ ). Using the principle of forming the more thermodynamically stable ${ }^{+} \mathrm{MgCl}$ intermediate (i.e. the 5 -alkoxide, analogous to $\mathbf{6 a}$ ), a selective mono-deacetylation of isosorbide-2,5-diacetate 5 
with $\mathrm{MeMgCl}$ (1.3 equiv) was carried out (Table 1 ). The multigram synthesis of isosorbide-2-acetate (2b) was achieved in $83 \%$ yield without the requirement for chromatography with diacetate 5 formed in situ from 1 using $\mathrm{Ac}_{2} \mathrm{O}$ and Amberlite ${ }^{\circledast}$ IR-120 catalyst.

With the 2- or 5-positions on isosorbide effectively blocked through acetylation, functionalization of the available hydroxyl with furoxan was now possible. Furoxan electrophiles $\mathbf{7 a}$ and $\mathbf{7} \mathbf{b}$ can be readily prepared in two steps from their respective cinnamyl alcohols (see Supporting Information). ${ }^{14,15}$ Alkylation with the furoxan bromides $7 \mathbf{a}$ and $7 \mathbf{b}$ was mediated by $\mathrm{Ag}_{2} \mathrm{O}$. Reaction of 5-acetate $\mathbf{2 a}$ with bromide 7a yielded isosorbide-5-acetate-2-furoxan $3 \mathbf{a}$ in $81 \%$ yield with furoxan attachment at the exo-position confirmed by X-ray crystallography (Scheme 3 ).

Scheme 3. Synthesis of isosorbide-2-furoxan $4 a$ and $\mathrm{X}$-ray crystal structure of $3 \mathrm{a}$ (thermal ellipsoids set at 40\% probability)

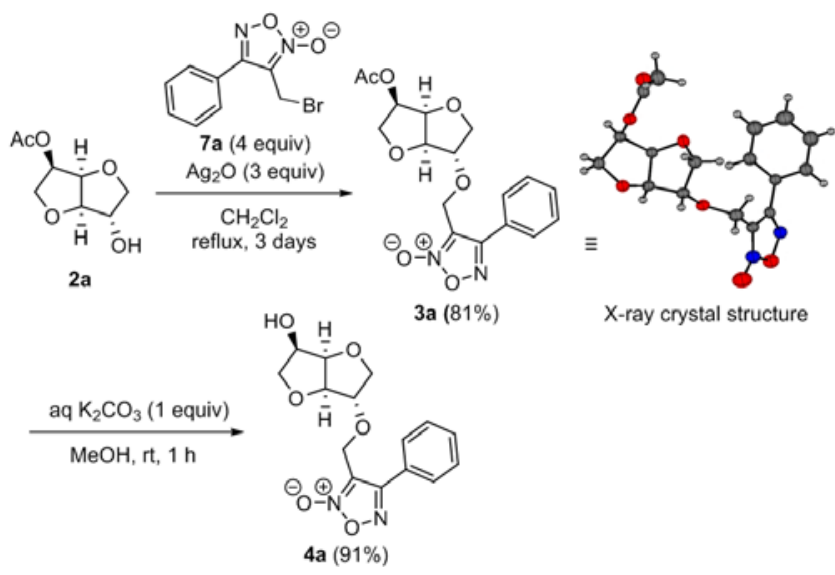

Deprotection of 5 -acetate 3 a through basic hydrolysis afforded isosorbide-2-furoxan $\mathbf{4 a}$ in $91 \%$ yield. Similarly, synthesis of furoxan isomer $\mathbf{4} \mathbf{b}$ from $\mathbf{2}$-acetate $\mathbf{2 b}$ via isosorbide-2-acetate-5-furoxan $\mathbf{3 b}$ occurred in an overall $90 \%$ yield over two steps of alkylation and deprotection (Scheme 4).

Scheme 4. Synthesis of isosorbide-5-furoxans 4 b and 4C and X-ray crystal structure depicting one of the two molecules in the asymmetric unit cell of $4 \mathrm{C}$ (thermal ellipsoids set at 50\% probability)

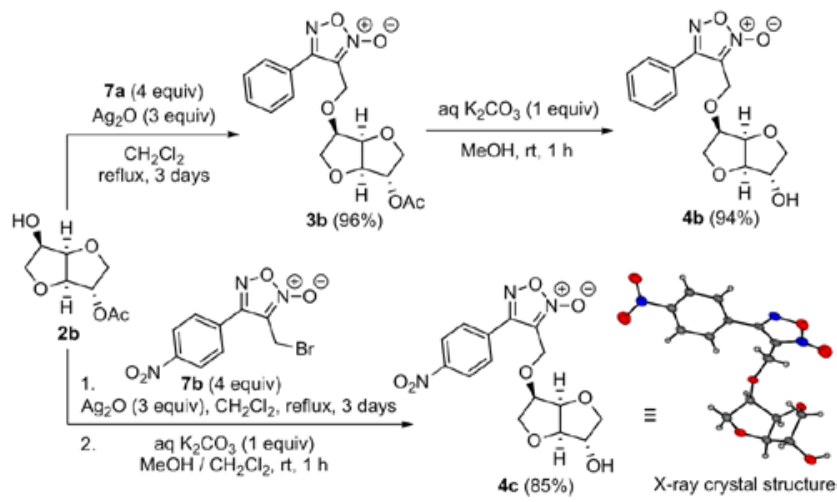

It is known that NO-production can be increased by substituting the furoxan ring with electron-withdrawing groups, such as nitrobenzene, which effectively increase susceptibility to addition of activating thiols (such as cysteine).13,14 Thus, in a quest to increase the activity of isosorbide- 5 -furoxan, the preparation of $p$-nitro derivative $4 \mathbf{c}$ was carried out from isosorbide-2-acetate $\mathbf{2} \mathbf{b}$ and bromide $\mathbf{7 b}$ (Scheme 4). $p$-Nitrophenyl-substituted furoxan $4 \mathrm{c}$ was isolated in $85 \%$ yield without the requirement for isolation of the intermediate isosorbide-2-acetate-5-furoxan.

To further increase the level of NO-release, isosorbide was functionalized with two furoxan moieties. The preparation of isosorbide-2,5-difuroxan 8 was achieved in $77 \%$ isolated yield by facile alkylation of $\mathbf{1}$ with $7 \mathbf{a}$ in the presence of $\mathrm{Ag}_{2} \mathrm{O}$ (Scheme 5). The X-ray crystal structure of bis-adduct 8 was obtained, and like the other two crystal structures (of $3 \mathbf{a}$ and 4c) provided a clear visual representation of the 2-exo and 5-endo isosorbide attachments (Schemes 3-5). H-bonding in the lattice only occurred in 4c, presumably due to the isosorbide hydroxyl being deacetylated, (Fig. S1o and Table $\mathrm{S}_{5} \mathrm{~B}$ ).

Scheme 5. Synthesis and X-ray crystal structure of isosorbide-2,5-difuroxan 8 (thermal ellipsoids set at $30 \%$ probability)

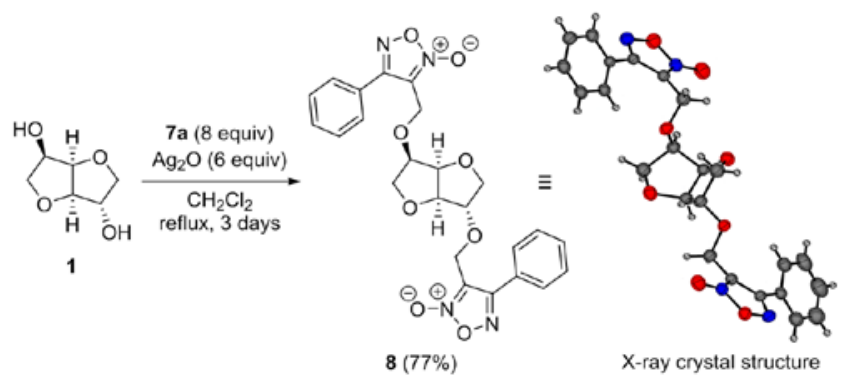

NO-release from our isosorbide furoxans was quantitatively measured along with that of the commercial vasodilator, Is 5 N. Furoxans have long been known to release NO upon reaction with thiols, including cysteine. ${ }^{12}$ DFT calculations supported the addition of a sulfanyl radical onto the $\mathrm{C}=\mathrm{N}$ bond of the furoxan followed by expulsion of $\mathrm{NO},{ }^{27}$ although others give alternative thiolate addition mechanisms, ${ }^{12,14}$ which are energetically less favourable. ${ }^{27}$ NO-release holds a reasonable correlation with vascular tissue relaxation in a series of furoxans. ${ }^{11,12} \mathrm{NO}$ is, however, never measured directly due to very rapid oxidation in aqueous and biological fluids to nitrite $\left(\mathrm{NO}_{2}^{-}\right)$and nitrate $\left(\mathrm{NO}_{3}{ }^{-}\right) .^{12,14}$ The amount of NO-released is commonly evaluated through $\mathrm{NO}_{2}^{-}$measurement using the Griess assay, in the presence of excess cysteine with the presence of $\mathrm{NO}_{3}$ deemed less significant. Using this approach, $\mathrm{NO}_{2}$ production from isosorbide-furoxans $3 \mathbf{a}, \mathbf{4 a - 4 \mathbf { c }}$ and $\mathbf{8}$ was quantitatively monitored by regular sampling (Figure $\mathrm{S}_{4}$ ), which indicated a 3-7.5 fold greater rate of release than Is $5 \mathbf{N}$ $\left(k_{\text {obs}}\right.$, Table 2$)$. After $12 \mathrm{~h}$ a significant slowdown for most furoxans was observed, apart from isosorbide-2,5-difuroxan 8, which exhibited a longer sustained NO-release. This retardation in $\mathrm{NO}$ release allowed measurement of the extent of $\mathrm{NO}_{2}{ }^{-}$production after $24 \mathrm{~h}$ (Table 2 ). A thorough approach was used with combined $\mathrm{NO}_{2}^{-}$and $\mathrm{NO}_{3}^{-}$measured. 
Nowadays this is possible using a commercially available colorimetric assay that measures total available $\mathrm{NO}_{2}{ }^{-}$after reduction of $\mathrm{NO}_{3}^{-}$to $\mathrm{NO}_{2}^{-}$by $\mathrm{NADPH}$ in the presence of the enzyme, nitrate reductase. ${ }^{28}$ Moreover, Table 2 shows $\mathrm{NO}_{3}$ levels were significant for some furoxans, especially the most reactive compounds highlighting the need for analysis.

\section{Table 2. Extent and rate of NO release}

\begin{tabular}{cccc}
$\begin{array}{c}\mathrm{NO} \\
\text { donor }\end{array}$ & $\begin{array}{c}\mathrm{NO}_{2}^{-} \\
\text {produced } \\
(\mathrm{mol} \%)^{a}\end{array}$ & $\begin{array}{c}\mathrm{NO}_{2}^{-}+\mathrm{NO}_{3}^{-} \\
\text {produced } \\
(\mathrm{mol} \%)^{b}\end{array}$ & $k_{\text {obs }}\left(\mathrm{h}^{-1}\right)^{c}$ \\
\hline $3 \mathbf{a}$ & $43.8 \pm 1.7$ & $45.2 \pm 1.6$ & 0.081 \\
$4 \mathbf{a}$ & $56.0 \pm 1.0$ & $61.7 \pm 3.5$ & 0.098 \\
$4 \mathbf{b}$ & $47.3 \pm 1.4$ & $47.4 \pm 0.7$ & 0.079 \\
$4 \mathbf{c}$ & $60.9 \pm 1.8$ & $67.5 \pm 1.6$ & 0.195 \\
$\mathbf{8}$ & $80.3 \pm 1.1$ & $94.5 \pm 4.0$ & 0.136 \\
Is5N & $19.0 \pm 0.6$ & $19.0 \pm 1.2$ & 0.026
\end{tabular}

${ }^{a}$ Determined by Griess assay after $24 \mathrm{~h}$ incubation of $2.0 \mathrm{mM}$ solutions with excess L-cysteine at $37{ }^{\circ} \mathrm{C}$. ${ }^{b}$ Samples of solutions after $24 \mathrm{~h}$ incubated with nitrate reductase prior to performing Griess assay. ${ }^{c}$ Rate constant $\left(k_{\text {obs }}\right)$ for $\mathrm{NO}_{2}{ }^{-}$ production calculated by linear regression analysis of $0-4 \mathrm{~h}$ data points for $4 \mathrm{c}$ and $\mathrm{o}-8 \mathrm{~h}$ data points for all other compounds in Figure $\mathrm{S}_{4}$.

The $p$-nitrophenyl-substituted derivative furoxan $4 \mathrm{c}$ had a significantly higher rate of NO-release, with this compound being the most active, with 2-2.5 times greater rate of $\mathrm{NO}_{2}$ production compared to isosorbide-2- and 5-furoxans $\mathbf{4 a}$ and 4b. High concentrations of NO have been related to anticancer activity for some furoxans. ${ }^{29}$ The acetate group of 3 a appeared to hinder NO-release with a slower rate, as well as a smaller total amount of NO produced compared to its hydrolyzed derivative 4a. As expected, substituting both available hydroxyls on isosorbide with furoxan in compound 8 almost doubled the extent of NO production, but the rate of NO-release was below that of the most reactive monosubstituted isosorbide furoxan 4c. Isosorbide-2-furoxan $\mathbf{4 a}^{\mathbf{a}}$ gave higher levels of NO-release compared to its isomer $\mathbf{4} \mathbf{b}$, and pharmacologically they would be expected to behave differently as shown by the drug $\mathbf{I} \mathbf{s}_{5} \mathbf{N}$, which is less potent than isosorbide-2-mononitrate (Is2 N), as a vasodilator. $3^{30}$

Differential Scanning Calorimetry (DSC) was used for assessment of thermally induced energy release, ${ }^{31}$ which allows deductions regarding safe handling in comparison with Is5 $\mathbf{N}$, which is classified as an explosive. ${ }^{22}$ The onset temperature for thermal degradation of phenyl furoxans (4a, 4b and 8) is less accessible at $66-94{ }^{\circ} \mathrm{C}$ above that of Is5N (Table 3). Similarly, the degradation exotherms peaked 61$73{ }^{\circ} \mathrm{C}$ above that of Is $5 \mathbf{N}$. The energy released from such exothermic events was lower for the phenyl furoxans by $1086-1614 \mathrm{~J} / \mathrm{g}$. The most active NO-releasing furoxan, $p$ nitrophenyl furoxan $4 \mathbf{C}$ is safer than Is5 $\mathbf{N}$ with a significantly higher onset and peak temperature by almost $32{ }^{\circ} \mathrm{C}$ and $41^{\circ} \mathrm{C}$ respectively, and with an energy release $1099 \mathrm{~J} / \mathrm{g}$ lower.

In summary, inexpensive $\mathrm{MeMgCl}$-mediated acetylation has afforded an effective and simple protection-deprotection for both hydroxyls of isosorbide. Subsequent functionalization with furoxan gave powerful nitric oxide donors with vastly higher rates and amounts of $\mathrm{NO}_{\mathrm{x}}$ produced compared to the commercial vasodilator, Is $5 \mathbf{N}$. Isosorbide-furoxans are safer to handle than Is5N. Future studies will focus on the biological evaluation of this new class of NO-donors.

Table 3. Exothermic events ${ }^{a}$

\begin{tabular}{cccc}
$\begin{array}{c}\text { NO } \\
\text { donor }\end{array}$ & $\begin{array}{c}\text { onset temp } \\
\left({ }^{\circ} \mathrm{C}\right)^{b}\end{array}$ & $\begin{array}{c}\text { peak temp } \\
\left({ }^{\circ} \mathrm{C}\right)^{c}\end{array}$ & $\begin{array}{c}\text { energy release } \\
(\mathrm{J} / \mathrm{g})^{d}\end{array}$ \\
\hline $\mathbf{4 a}$ & 231.0 & 271.8 & 1122.0 \\
$\mathbf{4 b}$ & 202.9 & 261.4 & 1474.5 \\
$4 \mathbf{C}$ & 168.3 & 241.7 & 1636.9 \\
$\mathbf{8}$ & 217.9 & 273.7 & 1649.5 \\
Is5N & 136.7 & 200.4 & 2735.8
\end{tabular}

${ }^{a}$ DSC was performed using $1.7-4.6 \mathrm{mg}$ of samples in a high pressure crucible, heating at $5{ }^{\circ} \mathrm{C} / \mathrm{min}$. ${ }^{b}$ Temperature at which the exothermic event begins. ${ }^{c}$ Temperature of maximal heat release. ${ }^{d}$ Calculated by integration.

\section{ASSOCIATED CONTENT}

\section{Supporting Information}

Detailed experimental, synthetic procedures, characterization data, NMR spectra, DFT, DSC and crystallographic data (PDF). This material is available free of charge via the Internet at http://pubs.acs.org.

\section{Accession Codes}

CCD 1830485,1830483 and 1830484 contain the supplementary data for compounds $3 \mathbf{a}, \mathbf{4 c}$ and $\mathbf{8}$ respectively. This data can be obtained free of charge via www.ccdc.cam.ac.uk/data_request/cif, or by emailing data_ request@ccdc.cam.ac.uk, or by contacting The Cambridge Crystallographic Data Centre, 12 Union Road, Cambridge CB2 1EZ, UK; fax: +44 1223336033 .

\section{AUTHOR INFORMATION}

\section{Corresponding Author}

*E-mail: f.aldabbagh@kingston.ac.uk

\section{ORCID}

Fawaz Aldabbagh: oooo-ooo1-8356-5258

\section{Notes}

The authors declare no competing financial interest.

\section{ACKNOWLEDGMENTS}

We thank the Irish Research Council (IRC) for awarding Patrick Kielty an Enterprise Partnership Postgraduate Scholarship in association with Avara Pharmaceutical Services, and MaryRose Kelleher (Avara Pharmaceutical Services, Shannon, Co. Clare, Ireland) Mary Kennedy (SPDS, Tarbert, Co. Kerry, Ireland), Gerard Fahy, John O'Reilly, and Seamus Collier (all School of Chemistry, 
National University of Ireland Galway, Ireland) for technical assistance.

\section{REFERENCES}

(1) Carpenter, A. W.; Schoenfisch, M. H. Chem. Soc. Rev. 2012, 41, 3742-3752.

(2) (a) Cheng, H.; Wang, L.; Mollica, M.; Re, A. T.; Wu, S.; Zuo, L. Cancer Lett. 2014, 353, 1-7. (b) Rizi, B. S.; Achreja, A.; Nagrath, D. Trends Cancer 2017, 3, 659-672.

(3) Jones, M. L.; Ganopolsky, J. G.; Labbé, A.; Wahl, C.; Prakash, S. Appl. Microbiol. Biotechnol. 2010, 88, 401-407.

(4) Witte, M. B.; Barbul, A. Am. J. Surg. 2002, 183, 406-412.

(5) (a) Lundberg, J. O.; Weitzberg, E.; Gladwin, M. T. Nat. Rev. Drug Discovery 2oo8, 7, 156-167. (b) Bohlen, H. G. Compr. Physiol. 2015, 5, 803-828.

(6) (a) Thatcher, G. R. J. Chem. Soc. Rev. 1998, 27, 331-337. (b) Ignarro, L. J.; Napoli, C.; Loscalzo, J. Circ. Res. 2002, 90, 21-28.

(7) Boschan, R.; Merrow, R. T.; van Dolah, R. W. Chem. Rev. 1955, 55, 485-510.

(8) Reddy, G. O.; Rao, A. S. J. Hazard. Mater. 1992, 32, 87104.

(9) (a) Klapötke, T. M.; Piercey, D. G.; Stierstorfer, J. Propellants, Explos., Pyrotech. 2011, 36, 16o-167. (b) He, C.; Shreeve, J. M. Angew. Chem. Int. Ed. 2016, 55, 772-775.

(10) Bohn, H.; Brendel, J.; Martorana, P. A.; Schönafinger, K. Br. J. Pharmacol. 1995, 114, 1605-1612.

(11) Gasco, A.; Fruttero, R.; Sorba, G.; Di Stilo, A.; Calvino, R. Pure Appl. Chem. 2004, 76, 973-981.

(12) (a) Medana, C.; Ermondi, G.; Fruttero, R.; Di Stilo, A.; Ferretti, C.; Gasco, A. J. Med. Chem. 1994, 37, 4412-4416. (b) Sorba, G.; Medana, C.; Fruttero, R.; Cena, C.; Di Stilo, A.; Galli, U.; Gasco, A. J. Med. Chem. 1997, 40, 463-469.

(13) Ferioli, R.; Folco, G. C.; Ferretti, C.; Gasco, A. M.; Medana, C.; Fruttero, R.; Civelli, M.; Gasco, A. Br. J. Pharmacol. 1995, 114, 816-820.

(14) Schiefer, I. T.; VandeVrede, L.; Fa', M.; Arancio, O.; Thatcher, G. R. J. J. Med. Chem. 2012, 55, 3076-3087.

(15) Tang, W.; Xie, J.; Xu, S.; Lv, H.; Lin, M.; Yuan, S.; Bai, J.; Hou, Q.; Yu, S. J. Med. Chem. 2014, 57, 7600-7612.

(16) Mayer, B.; Beretta, M. Br. J. Pharmacol. 20o8, 155, 170184 .

(17) Dussenne, C.; Delaunay, T.; Wiatz, V.; Wyart, H.; Suisse, I.; Sauthier, M. Green Chem. 2017, 19, 5332-5344.

(18) Rose, M.; Palkovits, R. ChemSusChem 2012, 5, 167-176.

(19) (a) Szeja, W. J. Chem. Soc., Chem. Commun. 1981, 215216. (b) Che, P.; Lu, F.; Nie, X.; Huang, Y.; Yang, Y.; Wang, F.; $\mathrm{Xu}, \mathrm{J}$. Chem. Commun. 2015, 51, 1077-1080.

(20) (a) Stoss, P.; Merrath, P.; Schlüter, G. Synthesis 1987, 174-176. (b) Abenhaïm, D.; Loupy, A.; Munnier, L.; Tamion,
R.; Marsais, F.; Quéguiner, G. Carbohydr. Res. 1994, 261, 255266.

(21) Lavergne, A.; Moity, L.; Molinier, V.; Aubry, J.-M. RSC Adv. 2013, 3, 5997-6007.

(22) Čeković, Ž.; Tokić, Z. Synthesis 1989, 610-612.

(23) Seemayer, R.; Bar, N.; Schneider, M. P. Tetrahedron: Asymmetry 1992, 3, 1123-1126.

(24) Harnett, G. J.; Hayes, J.; Reents, R.; Smith, D. A.; Walsh, A. U.S. Patent US20120071683, Sept 16, 2010.

(25) (a) Guggenberger, L. J.; Rundle, R. E. J. Am. Chem. Soc. 1968, 90, 5375-5378. (b) Peltzer, R. M.; Eisenstein, O.; Nova, A.; Cascella, M. J. Phys. Chem. B 2017, 121, 4226-4237.

(26) Frisch, M. J.; Trucks, G. W.; Schlegel, H. B.; Scuseria, G. E.; Robb, M. A.; Cheeseman, J. R.; Scalmani, G.; Barone, V.; Petersson, G. A.; Nakatsuji, H.; Li, X.; Caricato, M.; Marenich, A. V.; Bloino, J.; Janesko, B. G.; Gomperts, R.; Mennucci, B.; Hratchian, H. P.; Ortiz, J. V.; Izmaylov, A. F.; Sonnenberg, J. L.; Williams-Young, D.; Ding, F.; Lipparini, F.; Egidi, F.; Goings, J.; Peng, B.; Petrone, A.; Henderson, T.; Ranasinghe, D.; Zakrzewski, V. G.; Gao, J.; Rega, N.; Zheng, G.; Liang, W.; Hada, M.; Ehara, M.; Toyota, K.; Fukuda, R.; Hasegawa, J.; Ishida, M.; Nakajima, T.; Honda, Y.; Kitao, O.; Nakai, H.; Vreven, T.; Throssell, K.; Montgomery, J. A., Jr.; Peralta, J. E.; Ogliaro, F.; Bearpark, M. J.; Heyd, J. J.; Brothers, E. N.; Kudin, K. N.; Staroverov, V. N.; Keith, T. A.; Kobayashi, R.; Normand, J.; Raghavachari, K.; Rendell, A. P.; Burant, J. C.; Iyengar, S. S.; Tomasi, J.; Cossi, M.; Millam, J. M.; Klene, M.; Adamo, C.; Cammi, R.; Ochterski, J. W.; Martin, R. L.; Morokuma, K.; Farkas, O.; Foresman, J. B.; Fox, D. J. Gaussian 16W, Revision A.03, Gaussian, Inc., Wallingford CT, 2016.

(27) Burov, O. N.; Kletskii, M. E.; Fedik, N. S.; Lisovin, A. V.; Kurbatov, S. V. Chem. Heterocycl. Compd. 2015, 51, 951960.

(28) Hevel, J. M.; Marletta, M. A. Nitric-oxide Synthase Assays. In Methods Enzymol.; Packer, L., Ed.; Academic Press: San Diego, 1994; vol. 233, pp. 250-258.

(29) (a) Han, C.; Huang, Z.; Zheng, C.; Wan, L.; Zhang, L.; Peng, S.; Ding, K.; Ji, H.; Tian, J.; Zhang, Y. J. Med. Chem. 2013, 56, 4738-4748. (b) Liu, M.-M.; Chen, X.-Y.; Huang, Y.Q.; Feng, P.; Guo, Y.-L.; Yang, G.; Chen, Y. J. Med. Chem. 2014, 57, 9343-9356.

(30) Wendt, R. L. J. Pharmacol. Exp. Ther. 1972, 18o, 732742.

(31) Frurip, D. J.; Elwell, T. Process Saf. Prog. 2007, 26, 5158.

(32) Butler, A. R.; Pearson, R. J. Vasodilators for Biological Research. In Nitric Oxide Donors; Wang, P. G., Cai, T. B., Taniguchi, N., Eds.; Wiley-VCH: Weinheim, 2005; pp. 201231. 